\title{
Traditionally used wild edible plants of district Udhampur, J\&K, India
}

\author{
Harpreet Bhatia', Yash Pal Sharma', R. K. Manhas ${ }^{2^{*}}$ (D) and Kewal Kumar ${ }^{3}$
}

\begin{abstract}
Background: Wild edible plants (WEPs) refer to edible species that are not cultivated or domesticated. WEPs have an important role to play in poverty eradication, security of food availability, diversification of agriculture, generation of income resources, and alleviating malnutrition. In the present study, an inventory of traditionally used WEPs from Udhampur district of J\&K, India, has been prepared.

Methods: A systematic and extensive ethnobotanical survey was carried out in different villages of the district for the collection of information on WEPs. The data collected through questionnaire and interviews was then analyzed for cultural importance index $(\mathrm{Cl})$ and factor informant consensus $\left(F_{i c}\right)$ to know the cultural significance of WEPs and consensus for the knowledge of WEPs among the informants.
\end{abstract}

Results: A total of 90 plant species belonging to 45 families and 78 genera were edible and serve as wild phytofoods in the present study. Species richness of wild edible species was the maximum for vegetables (46 species) followed by fruits (37 species) and medicinal plants (36 species). Culturally (on the basis of $\mathrm{Cl}$ ), the most important vegetable and fruit species were Diplazium esculentum, Fumaria indica, Taraxacum campylodes, Urtica dioica, Phyllanthus emblica, Punica granatum, Cordia dichotoma, Syzygium cumini, Ficus palmata, etc. The highest use-report (626) was recorded for vegetables whereas the maximum mean use-report (14.8) was recorded for fruits. On an average, 20.7 wild edible species were used per informant. Informant consensus index $\left(F_{i \mathrm{ic}}\right)$ varied between 0.83 and 0.94 for raw vegetables and preserved vegetables, respectively.

Conclusion: One of the most important issues of this era is hunger for which one of the possible solutions is the usage of WEPs. The local populace of Udhampur has good knowledge of WEPs, and this legacy of traditional culture must be conserved.

Keywords: Cultural importance index, Traditionally used, Wild edible plants, Udhampur

\section{Introduction}

Wild edible plants (WEPs) refer to plant species that are not cultivated or domesticated but are accessible from various natural habitations and used as food [1]. WEPs are generally gathered from diverse habitats, viz, forests, cultivable fields, and even anthropogenically disturbed zones like roadsides and wastelands by different traditions throughout the world. A huge number of ethnic communities and local populace residing in the developing countries draw a significant part of their subsistence and livelihood from wild plants [2]. Historically, humans may have utilized more than 7000 WEPs so far [3], but

\footnotetext{
* Correspondence: manhasrk@rediffmail.com

²Department of Botany, Govt. Degree College, Kathua, J\&K 184104, India

Full list of author information is available at the end of the article
}

many such food resources and valuable plants are still to be explored [4].

Despite the fact that most of the societies primarily rely upon agricultural crops, the tradition of utilization of WEPs has not completely vanished. According to Food and Agricultural Organization (FAO) report, at least one billion people are thought to use wild food in their diet [5]. WEPs have important role to play in poverty eradication, security of food availability, diversification of agriculture, generation of income resources [6-8], and alleviation of malnutrition [5]. The high nutrient and vitamin value of many WEPs [9-12] reduces the susceptibility of local societies to food insecurity thereby furnishing a safeguard in times of food scarcity, famine, or conflict [13-17].

(c) The Author(s). 2018 Open Access This article is distributed under the terms of the Creative Commons Attribution 4.0 International License (http://creativecommons.org/licenses/by/4.0/), which permits unrestricted use, distribution, and 
WEPs have, by tradition, occupied an important position in the cultural, religious, and health sector of rural and ethnic lives of Indians. In India, the presence of varied climatic zones and ecological diversity creates a basis for rich phytodiversity and this fact is strongly supported by various studies carried out on WEPs by various researchers throughout India [18-29]. Arora and Anjula [30] have given a detailed account of WEP species occurring in India while Rathore [31] reported 600 WEP species from India. From J\&K state, there are only a few studies [32-36] regarding usage of WEPs.

District Udhampur, located in Jammu division of J\&K state, is a hilly terrain and many villages of the region are cut off from the frequent visits of the town. Since antiquity, the rural populace of the district has been dependent on wild plants as food because of their free availability, effectiveness against a background of undeveloped infrastructure, cultural and religious preferences, and insufficient provision of primary services. The main occupation of the local populace is agriculture. But, due to possession of small land holdings and insufficient earning, the male folk work either as laborers or are engaged in small home run shops like blacksmith and cobbler whereas the womenfolk and children are engaged in livestock rearing. On their to-and-fro journey to forests, they also collect WEPs for self-consumption and for sale in local markets as a source of income generation. The usage of WEPs has generated among them a strong base of traditional knowledge regarding phytofoods which in turn is based on their needs, instinct, observation, trial, and error coupled with experiences and has been providing them food security since antiquity. This knowledge base has developed through age-old experience and has descended orally from one generation to another as a domestic practice. But, in the present scenario, this tradition and associated knowledge is dwindling owing to developmental activities, migration from rural to urban areas for occupation and education, changing cultural traditions, attraction towards western ways of life, temptation of fast foods, declining natural resources [37-39], changing environmental conditions, deforestation, etc. [40, 41]. Balick and Cox [42] have also stated that modernization of traditions often results in the alteration of native knowledge systems as the whole community moves away from their conventional ways and adopts untraditional foreign principles. So, it is the prime need of our generation to collect and document this valuable traditional knowledge for the betterment of humanity. The present study was therefore undertaken to (i) inventorize this rich legacy of traditional knowledge available with the villagers of Udhampur district, (ii) find the cultural significance of WEPs, and (iii) evaluate consensus among the locals for the traditional knowledge of wild edible plants.

\section{Material and methods Study area}

District Udhampur, located in Jammu division of J\&K state, lying between $32^{\circ} 34^{\prime}$ and $39^{\circ} 30^{\prime}$ North latitude and $74^{\circ} 16^{\prime}$ and $75^{\circ} 38^{\prime}$ East longitude, has a total area of $2380 \mathrm{~km}^{2}$ (Fig. 1). The district is situated in the southeastern part of J\&K with an altitude ranging from 600 to 2900 $\mathrm{m}$ above mean sea level. The topography of the district is hilly, interwoven with the Shivalik range of the Himalayas, and has largely a difficult and rugged terrain divided into three geographic zones: (a) temperate/intermediate zone, (b) sub-tropical/intermediate zone, and (c) intermediate zone. The district has an average rainfall slightly over $1551 \mathrm{~mm}$ [40]. Most of the rainfall takes place during July, August, and September months. Snowfall usually occurs during December to February months and nearly 25\% of the study area remains snowbound during winter.

\section{Methodology \\ Survey and data collection}

A systematic and extensive ethno-botanical survey was carried out in different villages of the district during June 2014 to June 2017 for the collection of information on wild edible plant species being used by locals in the study area. Before initiating the present study, a detailed survey was conducted during which various villages were visited and information was gathered about the people having the knowledge of wild edible plants or those involved in collection and sale of these plants. During the survey, informants were selected randomly and information was gathered by conducting interviews and group discussions with the informants in their local language on the indigenous uses of wild flora as food. A total of 88 informants (52 females and 36 males) between the age group 12-80 years were interviewed with a questionnaire. The information collected included common wild edible plant species, local name of plant species, habit, flowering time, plant part used, and recipe prepared individually or in combination with other plants.

The specimens of plant species were collected from the study site and then identified from the herbaria of the Department of Botany, University of Jammu, Jammu, and Indian Institute of Integrative Medicine, Jammu, and also with the help of various regional floras [43, 44]. The final list of the plants was prepared following the International Plant Names Index (http://www.ipni.org) and Tropicos (2017) for the botanical nomenclature of species. The plant specimens were submitted to the herbarium of the Department of Botany, University of Jammu, Jammu, J\&K, India.

\section{Data analysis}

The wild edible plants were classified into nine categories based upon the local usage and recipes (Table 1). The 


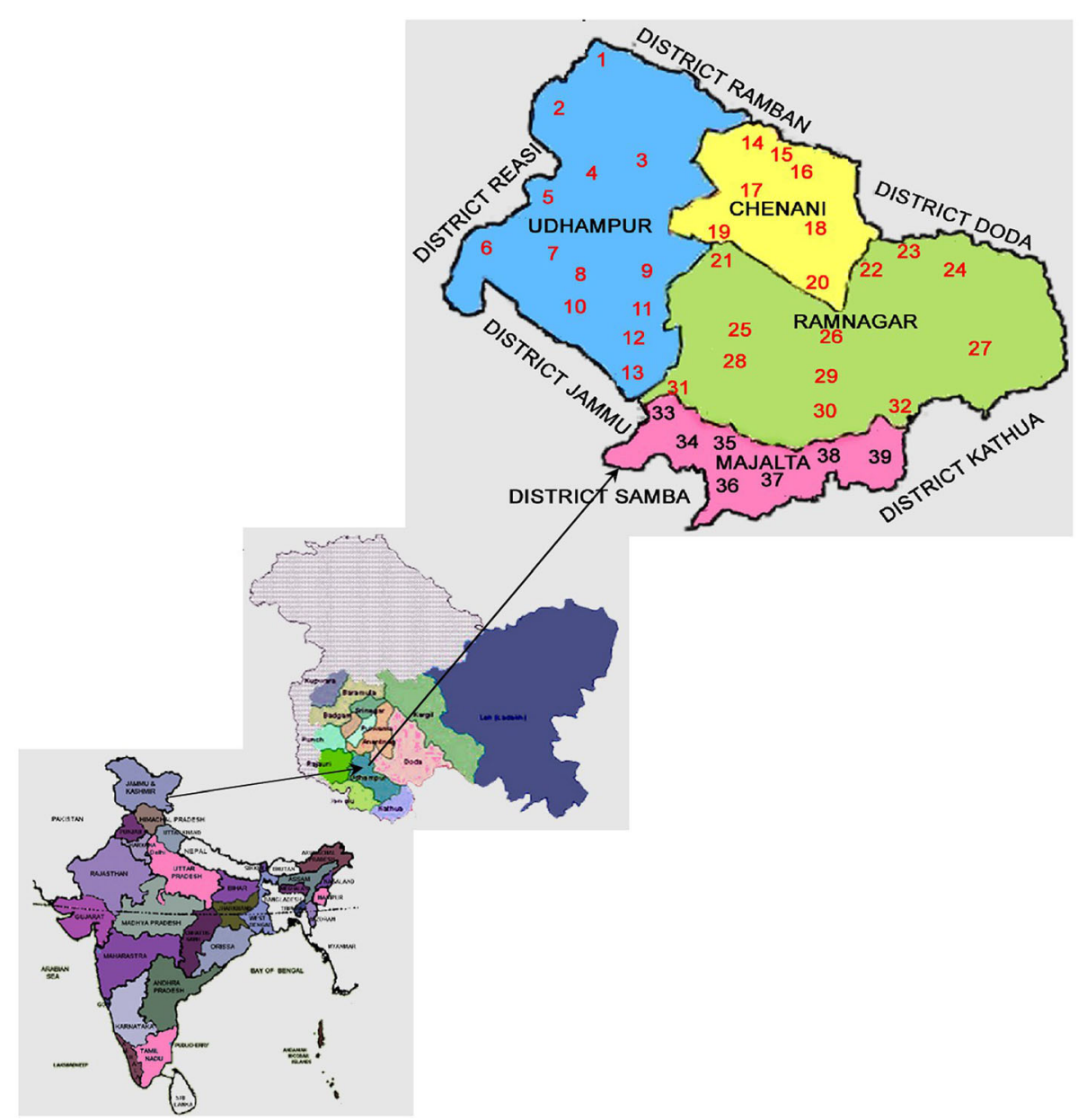

Fig. 1 Location map of the study along with the villages (numbered 1-39) in which study was conducted

vegetable use category was further subcategorized as cooked $\left(\mathrm{Veg}_{\mathrm{C}}\right)$, raw $\left(\mathrm{Veg}_{\mathrm{R}}\right)$, and preserved $\left(\mathrm{Veg}_{\mathrm{P}}\right)$. The vegetables which are consumed after cooking, grinding or boiling, and mixing with yogurt were categorized as cooked whereas preparations preserved in mustard oil and consumed as food during shortage period were classified as preserved and those consumed directly after washing or as salad were designated as raw. Fruit usage was subcategorized as raw $\left(\mathrm{Fr}_{\mathrm{R}}\right)$ and processed $\left(\mathrm{Fr}_{\mathrm{P}}\right)$. Due to less number of fruit species, both cooked and preserved subcategories were merged as processed. Other categories included spices $(\mathrm{Sp})$, beverages (Bv), and medicinal plants (Med).

The field information gathered through questionnaire and interviews was analyzed quantitatively using two ethnobotanical indices described as follows.

Factor informant consensus $\left(\boldsymbol{F}_{\mathrm{ic}}\right)$ To test the homogeneity of knowledge about the medicinal plants, the factor informant consensus $\left(F_{\text {ic }}\right)$ was used [45]. The $F_{\text {ic }}$ was calculated as:

$$
F_{\mathrm{ic}}=\frac{n_{\mathrm{ur}}-n_{\mathrm{t}}}{n_{\mathrm{ur}}-1}
$$

where $n_{\mathrm{ur}}$ refers to the number of use-reports for a particular use category and $n_{\mathrm{t}}$ refers to the number of taxa used for a particular use category by all the informants. $F_{\text {ic }}$ values are low (near 0 ) if plants are chosen randomly or if there is no exchange of information about their use among informants, and approach one (1) when there is a well-defined selection criterion in the community and/or if information is exchanged between informants [46, 47].

Cultural importance index (CI) The cultural importance index (CI) is defined by the following formula [48]:

$$
\mathrm{CI}_{\mathrm{s}}=\left[\sum_{u=u_{1}}^{u_{\mathrm{NC}}} \sum_{i=i_{1}}^{u_{N}} U R_{u i / N}\right]
$$

$\mathrm{CI}$ index can also be seen as the sum of the proportion of informants that mention each species use. This additive index takes into account not only the spread of the use (number of informants) for each species but also its 
Table 1 Edible usages and culture index of wild edible species of Udhampur district

\begin{tabular}{|c|c|c|c|c|c|c|c|}
\hline Botanical name & Family & $\begin{array}{l}\text { Voucher } \\
\text { no. (JUH) }\end{array}$ & Local name & $\begin{array}{l}\text { Life } \\
\text { form }\end{array}$ & $\begin{array}{l}\text { Plant part } \\
\text { used }\end{array}$ & Edible usage & $\mathrm{Cl}$ \\
\hline $\begin{array}{l}\text { Acacia catechu (L. f.) } \\
\text { Willd. }\end{array}$ & Leguminosae & 14552 & Katha & Tree & $\begin{array}{l}\text { Heartwood, } \\
\text { branches }\end{array}$ & Tea; medicinal. & 0.23 \\
\hline $\begin{array}{l}\text { Aegle marmelos (L.) } \\
\text { Correa }\end{array}$ & Rutaceae & 14594 & Bel patri & Tree & Fruits & $\begin{array}{l}\text { Fruit pulp is eaten fresh. Fruits are eaten raw and } \\
\text { infusion is sieved for making sharbat (cooling drink); } \\
\text { fruit is used as medicine. }\end{array}$ & 0.34 \\
\hline Agave americana L. & Asparagaceae & 14605 & Kyora & Shrub & Flowers & Vegetable, pickled. & 0.10 \\
\hline Amaranthus viridis $L$. & Amaranthaceae & 14452 & Chaleree & Herb & Leaves & Vegetable; medicinal. & 0.28 \\
\hline $\begin{array}{l}\text { Artemisia scoparia } \\
\text { Waldst. \& Kitam. }\end{array}$ & Compositae & 14606 & Chaau & Herb & $\begin{array}{l}\text { Seeds, } \\
\text { flowers, } \\
\text { leaves }\end{array}$ & Condiment, spice; medicinal. & 0.34 \\
\hline $\begin{array}{l}\text { Artocarpus lacucha } \\
\text { Buch.-Ham. }\end{array}$ & Moraceae & 14607 & Taeoo & Tree & Fruits & Pickled. & 0.30 \\
\hline $\begin{array}{l}\text { Asparagus } \\
\text { adscendens Roxb. }\end{array}$ & Asparagaceae & 14470 & Sanspour & Herb & Tubers & Vegetable, pickled, used as salad; medicinal. & 0.31 \\
\hline $\begin{array}{l}\text { Bauhinia vahlii Wight } \\
\text { \& Arn. }\end{array}$ & Leguminosae & 14493 & Malungarh & Climber & Seeds & $\begin{array}{l}\text { Seeds are consumed after roasting/frying; flower } \\
\text { buds are added to yogurt to make raita or aasara, } \\
\text { pickled. }\end{array}$ & 0.13 \\
\hline Bauhinia variegata $\mathrm{L}$. & Leguminosae & 14494 & Kartair & Tree & Flowers & $\begin{array}{l}\text { Vegetable is prepared in yogurt; flower buds are } \\
\text { added to yogurt to make raita or aasara, pickled. }\end{array}$ & 0.17 \\
\hline Berberis lycium Royle & Berberidaceae & 14484 & Kambel & Shrub & Fruits & Fruits are eaten raw; root is medicinal. & 0.43 \\
\hline Bombax ceiba $\mathrm{L}$. & Malvaceae & 14608 & Simbal & Tree & $\begin{array}{l}\text { Flower } \\
\text { receptacle }\end{array}$ & Vegetable. & 0.15 \\
\hline $\begin{array}{l}\text { Buglossoides arvensis } \\
\text { (L.) I. M. Johnst. }\end{array}$ & Boraginaceae & 14609 & Bibru & Herb & Fruits & Fruits are eaten raw. & 0.10 \\
\hline $\begin{array}{l}\text { Capsella bursa- } \\
\text { pastoris (L.) Medik. }\end{array}$ & Brassicaceae & 14692 & Chiri halian & Herb & Leaves & Vegetable. & 0.08 \\
\hline Cardamine impatiens $\mathrm{L}$. & Brassicaceae & 14870 & Daraati & Herb & Leaves & Vegetable. & 0.08 \\
\hline Carissa spinarum L. & Apocynaceae & 14463 & Garna & Shrub & Fruits & Fruits are eaten raw. & 0.22 \\
\hline Carum carvi L. & Apiaceae & 14940 & Shia jeera & Herb & Fruits, seeds & Spice, condiment. & 0.07 \\
\hline $\begin{array}{l}\text { Celastrus paniculatus } \\
\text { Willd. }\end{array}$ & Celastraceae & 14610 & Sankhir & Shrub & Fruits & Fruits are eaten raw. & 0.09 \\
\hline $\begin{array}{l}\text { Chenopodium } \\
\text { album L. }\end{array}$ & Amaranthaceae & 14504 & Bathu & Herb & Leaves & Vegetable. & 0.16 \\
\hline $\begin{array}{l}\text { Cissampelos } \\
\text { glaberrima A. St.-Hill. }\end{array}$ & Menispermaceae & 14550 & Battal bel & Climber & Leaves & $\begin{array}{l}\text { Pakora (prepared by deep frying leaves coated with } \\
\text { wheat flour), chutney (prepared by grinding leaves); } \\
\text { medicinal. }\end{array}$ & 0.40 \\
\hline $\begin{array}{l}\text { Citrus aurantiifolia } \\
\text { (Christm.) Swingle }\end{array}$ & Rutaceae & 14611 & Jambiri & Tree & Fruits & Juice is added to chutneys, eaten raw. & 0.23 \\
\hline Citrus medica L. & Rutaceae & 14596 & Gargal & Tree & Fruits & Pickled, juice is added to chutneys; medicinal. & 0.40 \\
\hline $\begin{array}{l}\text { Colocasia esculenta } \\
\text { (L.) Schott }\end{array}$ & Araceae & 14612 & Kachaloo & Herb & Tubers & $\begin{array}{l}\text { Boiled and eaten with spices and juice of Citrus } \\
\text { medica; cooked as vegetable. }\end{array}$ & 0.20 \\
\hline $\begin{array}{l}\text { Commelina } \\
\text { benghalensis L. }\end{array}$ & Commelinaceae & 14505 & Chura & Herb & Leaves & Vegetable. & 0.05 \\
\hline $\begin{array}{l}\text { Cordia dichotoma } \mathrm{G} . \\
\text { Forst. }\end{array}$ & Boraginaceae & 14613 & Lasoora & Tree & Fruits & Vegetable and pickled. & 0.51 \\
\hline $\begin{array}{l}\text { Cucumis melo var. } \\
\text { utilissimus (Roxb.) } \\
\text { Duthie \& Fuller }\end{array}$ & Cucurbitaceae & 14614 & Tar & Climber & Fruits & As salad. & 0.17 \\
\hline Cydonia oblonga Mill. & Rosaceae & 14615 & Bai dana & Tree & Fruits & $\begin{array}{l}\text { Fruits are eaten raw, murabba (prepared by shade } \\
\text { drying boiled fruits and preserving them in sugar). }\end{array}$ & 0.26 \\
\hline Dioscorea belophylla & Dioscoreaceae & 14616 & Tarar bail & Herb & Tubers & Vegetable, pickle; medicinal. & 0.24 \\
\hline
\end{tabular}


Table 1 Edible usages and culture index of wild edible species of Udhampur district (Continued)

\begin{tabular}{|c|c|c|c|c|c|c|c|}
\hline Botanical name & Family & $\begin{array}{l}\text { Voucher } \\
\text { no. (JUH) }\end{array}$ & Local name & $\begin{array}{l}\text { Life } \\
\text { form }\end{array}$ & $\begin{array}{l}\text { Plant part } \\
\text { used }\end{array}$ & Edible usage & $\mathrm{Cl}$ \\
\hline Diospyros lotus L. & Ebenaceae & 14617 & Amlook & Tree & Fruits & Dried fruits are eaten; medicinal. & 0.16 \\
\hline $\begin{array}{l}\text { Diplazium esculentum } \\
\text { (Retz.) Sw. }\end{array}$ & Athyriaceae & 14618 & Kasroor & Herb & Fronds & Vegetable, pickled. & 0.32 \\
\hline $\begin{array}{l}\text { Duchesnea indica } \\
\text { (Jacks.) Focke }\end{array}$ & Rosaceae & 14619 & $\begin{array}{l}\text { Jangali } \\
\text { shatawari }\end{array}$ & Herb & Fruits & Fruits are eaten raw; medicinal. & 0.09 \\
\hline $\begin{array}{l}\text { Elaeagnus parvifolia } \\
\text { wall. ex Royle }\end{array}$ & Elaeagnaceae & 14620 & Kaain & Shrub & Fruits & Fruits are eaten raw. & 0.02 \\
\hline $\begin{array}{l}\text { Euphorbia royleana } \\
\text { Boiss. }\end{array}$ & Euphorbiaceae & 14515 & Thor & Shrub & $\begin{array}{l}\text { Young } \\
\text { shoots }\end{array}$ & $\begin{array}{l}\text { Young shoots are boiled, cut into small pieces, and } \\
\text { added to yogurt to make raita or aasra; medicinal. }\end{array}$ & 0.07 \\
\hline $\begin{array}{l}\text { Fagopyrum acutatum } \\
\text { (Lehm.) Mansf. ex K. } \\
\text { Hammer }\end{array}$ & Polygonaceae & 14621 & $\begin{array}{l}\text { Van } \\
\text { daraiyoon }\end{array}$ & Herb & $\begin{array}{l}\text { Leaves, } \\
\text { seeds }\end{array}$ & $\begin{array}{l}\text { Vegetable; chapatti of flour are eaten during severe } \\
\text { cold. }\end{array}$ & 0.06 \\
\hline Ficus auriculata Lour. & Moraceae & 14622 & Trimbal & Tree & Fruits & Fruits are eaten raw. & 0.06 \\
\hline Ficus palmata Forssk. & Moraceae & 14557 & Phagwara & Tree & $\begin{array}{l}\text { Young } \\
\text { leaves, } \\
\text { fruits }\end{array}$ & $\begin{array}{l}\text { Young leaves are cooked with diluted yogurt to } \\
\text { make curry, leaves are also cooked with meat; fruits } \\
\text { are eaten raw; medicinal. }\end{array}$ & 0.43 \\
\hline Ficus racemosa $\mathrm{L}$. & Moraceae & 14558 & Rumbal & Tree & Fruits & Fruits are eaten raw. & 0.15 \\
\hline $\begin{array}{l}\text { Flacourtia indica } \\
\text { (Burm. f.) Merr. }\end{array}$ & Salicaceae & 14623 & Kakooaa & Tree & $\begin{array}{l}\text { Fruits, } \\
\text { inner bark }\end{array}$ & Fruits are eaten raw; tea. & 0.19 \\
\hline $\begin{array}{l}\text { Flemingia prostrata } \\
\text { Roxb. }\end{array}$ & Leguminosae & 14624 & Titri & Shrub & Fruits, seeds & Chutney (prepared by grinding fruits and seeds). & 0.06 \\
\hline $\begin{array}{l}\text { Fumaria indica } \\
\text { (Hausskn.) Pusley }\end{array}$ & Papaveraceae & 14528 & $\begin{array}{l}\text { Pitpapra, } \\
\text { indu }\end{array}$ & Herb & Leaves & Vegetable; medicinal. & 0.51 \\
\hline $\begin{array}{l}\text { Impatiens bicolor } \\
\text { Royle }\end{array}$ & Balsaminaceae & 14625 & Alwa & Herb & Seeds & Fruits are eaten raw. & 0.03 \\
\hline $\begin{array}{l}\text { Indigofera } \\
\text { cassioides DC. }\end{array}$ & Leguminosae & 14626 & Kathi & Shrub & Flowers & Vegetable. & 0.05 \\
\hline Juglans regia $\mathrm{L}$. & Juglandaceae & 14531 & Akhrot & Tree & Fruits & Fruits are eaten raw, chutney is prepared; medicinal. & 0.30 \\
\hline $\begin{array}{l}\text { Lamium amplexicaule } \\
\text { L. }\end{array}$ & Lamiaceae & 14627 & Indu saag & Herb & $\begin{array}{l}\text { Leaves, } \\
\text { young } \\
\text { shoots }\end{array}$ & Vegetable. & 0.03 \\
\hline Lathyrus aphaca L. & Leguminosae & 14628 & $\begin{array}{l}\text { Khand khiru, } \\
\text { mithu saag }\end{array}$ & Herb & $\begin{array}{l}\text { Leaves, } \\
\text { young } \\
\text { shoots, } \\
\text { seeds }\end{array}$ & $\begin{array}{l}\text { Vegetable, young seeds are eaten; fruits are eaten } \\
\text { raw. }\end{array}$ & 0.15 \\
\hline Malva parviflora $\mathrm{L}$. & Malvaceae & 14546 & Sonchal & Herb & Leaves & Vegetable. & 0.20 \\
\hline $\begin{array}{l}\text { Medicago } \\
\text { polymorpha L. }\end{array}$ & Leguminosae & 14740 & Sriri & Herb & Leaves & Vegetable; medicinal. & 0.34 \\
\hline Mentha longifolia (L.) L. & Lamiaceae & 14535 & Mainani & Herb & Leaves & Chutney; tea; medicinal. & 0.70 \\
\hline Moringa oleifera Lam. & Moringaceae & 14629 & Sohanjana & Tree & Pods, roots & Vegetable, pickle; medicinal. & 0.35 \\
\hline Morus alba $\mathrm{L}$. & Moraceae & 14560 & Shtoot & Tree & Fruits & Fruits are eaten raw; medicinal. & 0.28 \\
\hline Morus nigra L. & Moraceae & 14872 & Kala toot & Tree & Fruits & Fruits are eaten raw; medicinal. & 0.17 \\
\hline $\begin{array}{l}\text { Murraya koenigii (L.) } \\
\text { Spreng. }\end{array}$ & Rutaceae & 14630 & $\begin{array}{l}\text { Kari patta, } \\
\text { drankari }\end{array}$ & Shrub & Leaves & Spice; medicinal. & 0.14 \\
\hline $\begin{array}{l}\text { Nelumbo nucifera } \\
\text { Gaertn. }\end{array}$ & Nelumbonaceae & 14631 & Nadroo & Herb & Roots & $\begin{array}{l}\text { Vegetable is prepared either with tomato puree or } \\
\text { yogurt (dish is locally called nadroo ki yakhni) }\end{array}$ & 0.06 \\
\hline $\begin{array}{l}\text { Nepeta laevigata } \\
\text { (D. Don) Hand.-Mazz. }\end{array}$ & Lamiaceae & 14632 & Kaali khari & Herb & Fruits & Fruits are eaten raw. & 0.03 \\
\hline Ocimum basilicum L. & Lamiaceae & 14536 & $\begin{array}{l}\text { Babbari, } \\
\text { Naazposh }\end{array}$ & Herb & Seeds & $\begin{array}{l}\text { Sharbat (cooling drink prepared as infusion or } \\
\text { decoction); medicinal. }\end{array}$ & 0.03 \\
\hline Oxalis corniculata L. & Oxalidaceae & 14569 & Ammi & Herb & Leaves & Chutney; medicinal. & 0.08 \\
\hline Persicaria & Phyllanthaceae & 14580 & Aambla & Tree & Fruits & Tea. & 0.06 \\
\hline
\end{tabular}


Table 1 Edible usages and culture index of wild edible species of Udhampur district (Continued)

\begin{tabular}{|c|c|c|c|c|c|c|c|}
\hline Botanical name & Family & $\begin{array}{l}\text { Voucher } \\
\text { no. (JUH) }\end{array}$ & Local name & $\begin{array}{l}\text { Life } \\
\text { form }\end{array}$ & $\begin{array}{l}\text { Plant part } \\
\text { used }\end{array}$ & Edible usage & $\mathrm{Cl}$ \\
\hline \multicolumn{8}{|l|}{$\begin{array}{l}\text { amplexicaulis } \\
\text { (D. Don) Ronse Decr. }\end{array}$} \\
\hline $\begin{array}{l}\text { Phoenix sylvestris } \\
\text { (L.) Roxb. }\end{array}$ & Arecaceae & 14633 & Khajoor & Tree & Fruits & Fruits are eaten raw. & 0.10 \\
\hline $\begin{array}{l}\text { Phyllanthus } \\
\text { emblica L. }\end{array}$ & Plantaginaceae & 14517 & Challa & Herb & Leaves & Fruits are eaten raw, pickle, murabba; medicinal. & 0.86 \\
\hline $\begin{array}{l}\text { Plantago } \\
\text { lanceolata L. }\end{array}$ & Polygonaceae & 14725 & Masloon & Herb & Roots & Vegetable. & 0.03 \\
\hline Prunus armeniaca $\mathrm{L}$. & Rosaceae & 14587 & Saari, haari & Tree & Fruits & Fruits are eaten raw. & 0.30 \\
\hline $\begin{array}{l}\text { Prunus persica } \\
\text { (L.) Batsch }\end{array}$ & Rosaceae & 14588 & Aaru, aarn & Tree & Fruits & Fruits are eaten raw. & 0.33 \\
\hline $\begin{array}{l}\text { Pueraria tuberosa } \\
\text { (Willd.) DC. }\end{array}$ & Leguminosae & 14634 & Bidda & Climber & Tubers & Fruits are eaten raw and cooked as vegetable. & 0.10 \\
\hline Punica granatum L. & Lythraceae & 14542 & Darooni & Tree & Fruits, seeds & $\begin{array}{l}\text { Fruits are eaten raw, anaardana (dried seeds) are } \\
\text { ground to make chutney; medicinal. }\end{array}$ & 0.68 \\
\hline $\begin{array}{l}\text { Pyrus pashia Buch.- } \\
\text { Ham. ex D.Don }\end{array}$ & Rosaceae & 14589 & $\begin{array}{l}\text { Batangi, } \\
\text { kainth }\end{array}$ & Tree & Fruits & Fruits are eaten raw. & 0.02 \\
\hline $\begin{array}{l}\text { Ranunculus } \\
\text { arvensis } L \text {. }\end{array}$ & Ranunculaceae & 14858 & Tilphari & Herb & Whole plant & $\begin{array}{l}\text { Whole plant in vegetative stage is washed, sun } \\
\text { dried, and oil and tatri are added and consumed as } \\
\text { pickle. }\end{array}$ & 0.03 \\
\hline Rosa indica L. & Rosaceae & 14590 & Gulaab & Shrub & Petals & $\begin{array}{l}\text { Gulukand (prepared by preserving petals in sugar); } \\
\text { medicinal. }\end{array}$ & 0.15 \\
\hline Rubus ellipticus Sm. & Rosaceae & 14592 & Aakhe & Shrub & Fruits & Fruits are eaten raw. & 0.18 \\
\hline Rumex dentatus $\mathrm{L}$. & Polygonaceae & 14581 & Tandalak & Herb & Leaves & Vegetable. & 0.07 \\
\hline $\begin{array}{l}\text { Rumex hastatus } \\
\text { D. Don }\end{array}$ & Polygonaceae & 14582 & Ammi & Herb & Leaves & Vegetable, chutney. & 0.22 \\
\hline $\begin{array}{l}\text { Rumex nepalensis } \\
\text { Spreng. }\end{array}$ & Polygonaceae & 14635 & Urval & Herb & Leaves & Vegetable, curry made in yogurt. & 0.27 \\
\hline $\begin{array}{l}\text { Scandix pecten- } \\
\text { veneris } \mathrm{L} \text {. }\end{array}$ & Apiaceae & 14636 & $\begin{array}{l}\text { Bhuss, } \\
\text { indu saag }\end{array}$ & Herb & $\begin{array}{l}\text { Young } \\
\text { shoots }\end{array}$ & Vegetable. & 0.02 \\
\hline Silene conoidea $\mathrm{L}$. & Caryophyllaceae & 14502 & Takla & Herb & $\begin{array}{l}\text { Leaves, } \\
\text { fruits }\end{array}$ & Vegetable; fruits are eaten raw. & 0.13 \\
\hline $\begin{array}{l}\text { Stellaria media } \\
\text { (L.) Vill. }\end{array}$ & Caryophyllaceae & 14850 & $\begin{array}{l}\text { Koukoon, } \\
\text { laadroon }\end{array}$ & Herb & $\begin{array}{l}\text { Leaves, } \\
\text { shoots }\end{array}$ & Vegetable. & 0.02 \\
\hline $\begin{array}{l}\text { Syzygium cumini } \\
\text { (L.) Skeels }\end{array}$ & Myrtaceae & 14564 & Tallay & Tree & Fruits & Fruits are eaten raw; medicinal. & 0.57 \\
\hline $\begin{array}{l}\text { Taraxacum } \\
\text { campylodes } \\
\text { G. E. Haglund }\end{array}$ & Compositae & 14480 & Phul dudhli & Herb & Leaves & Vegetable; medicinal. & 0.50 \\
\hline $\begin{array}{l}\text { Telosma cordata } \\
\text { (Burm. F.) Merr. }\end{array}$ & Apocynaceae & 14637 & $\begin{array}{l}\text { Guaal } \\
\text { manda }\end{array}$ & Climber & Flowers & Vegetable, eaten raw. & 0.14 \\
\hline $\begin{array}{l}\text { Terminalia arjuna } \\
\text { (Roxb. ex DC.) } \\
\text { Wight \& Arn. }\end{array}$ & Combretaceae & 14638 & Arjan & Tree & Fruits & Fruits are eaten raw; medicinal. & 0.15 \\
\hline $\begin{array}{l}\text { Terminalia bellirica } \\
\text { (Gaertn.) Roxb. }\end{array}$ & Combretaceae & 14639 & Bahera & Tree & Fruits & $\begin{array}{l}\text { Fruits are eaten raw after removing outer covering; } \\
\text { medicinal. }\end{array}$ & 0.41 \\
\hline $\begin{array}{l}\text { Terminalia } \\
\text { chebula Retz. }\end{array}$ & Combretaceae & 14640 & Reer & Tree & Fruits & Vegetable, curry; medicinal. & 0.22 \\
\hline Trifolium pratense $\mathrm{L}$. & Leguminosae & 14774 & Shataala & Herb & $\begin{array}{l}\text { Leaves, } \\
\text { shoots }\end{array}$ & Vegetable; medicinal. & 0.11 \\
\hline Trifolium repens $\mathrm{L}$. & Leguminosae & 14798 & Chaptal & Herb & Leaves & Vegetable; medicinal. & 0.08 \\
\hline Tulipa clusiana DC. & Liliaceae & 14697 & $\begin{array}{l}\text { Maghey, } \\
\text { kayaloon, }\end{array}$ & Herb & Tubers & Tubers are eaten raw. & 0.02 \\
\hline
\end{tabular}


Table 1 Edible usages and culture index of wild edible species of Udhampur district (Continued)

\begin{tabular}{|c|c|c|c|c|c|c|c|}
\hline Botanical name & Family & $\begin{array}{l}\text { Voucher } \\
\text { no. (JUH) }\end{array}$ & Local name & $\begin{array}{l}\text { Life } \\
\text { form }\end{array}$ & $\begin{array}{l}\text { Plant part } \\
\text { used }\end{array}$ & Edible usage & $\mathrm{Cl}$ \\
\hline & & & kukarboona & & & & \\
\hline Urtica dioica $\mathrm{L}$. & Urticaceae & 14772 & Saddar & Herb & $\begin{array}{l}\text { Young } \\
\text { leaves and } \\
\text { shoots }\end{array}$ & Vegetable; beverage; medicinal. & 0.49 \\
\hline Veronica persica Poir. & Plantaginaceae & 14754 & Titi & Herb & $\begin{array}{l}\text { Young } \\
\text { leaves and } \\
\text { shoots }\end{array}$ & Vegetable is prepared in yogurt. & 0.05 \\
\hline $\begin{array}{l}\text { Viburnum } \\
\text { grandiflorum } \\
\text { Wall. ex DC. }\end{array}$ & Adoxaceae & 14641 & Taildi & Shrub & Fruits & Fruits are eaten raw. & 0.02 \\
\hline Vicia hirsuta (L.) Gray & Leguminosae & 14642 & Kanghi & Herb & Pods & Pods are eaten raw. & 0.01 \\
\hline Vicia sativa $\mathrm{L}$. & Leguminosae & 14934 & Jawaal & Herb & $\begin{array}{l}\text { Leaves, } \\
\text { young } \\
\text { shoots, } \\
\text { seeds }\end{array}$ & $\begin{array}{l}\text { Vegetable is prepared from leaves; dried seeds are } \\
\text { cooked as pulse; fresh seeds are eaten raw. }\end{array}$ & 0.09 \\
\hline Viola odorata L. & Violaceae & 15752 & Banafsha & Herb & Flowers & Tea; medicinal. & 0.39 \\
\hline $\begin{array}{l}\text { Zanthoxylum } \\
\text { armatum DC. }\end{array}$ & Rutaceae & 14597 & Timbru & Shrub & Seeds, fruits & $\begin{array}{l}\text { Chutney is prepared from seeds; fruits are sun dried, } \\
\text { fried in oil, and used as pickle; medicinal. }\end{array}$ & 0.42 \\
\hline Zizyphus jujuba Mill. & Rhamnaceae & 14767 & Ber & Tree & Fruits & Fruits are eaten raw; medicinal. & 0.27 \\
\hline
\end{tabular}

versatility, i.e., the diversity of its uses. The theoretical maximum value of the index is the total number of different use-categories (NC), reached in the unlikely case that all the informants would mention the use of the species in all the use-categories considered in a survey. In the case of species with only one use, this index would be equal to RFC [48].

\section{Results and discussion Informants}

Wild edible plants remain a significant source of food and income for many countryside populations of the world. In the present study, the main occupation of the local populace is agriculture. But due to small land holdings, the male folk work either as laborers or are engaged in small home run shops, blacksmiths, cobblers, etc. Knowledge about wild vegetables and their recipes was mainly confined to women folk (86.4\%). This unequal distribution of knowledge owes to the fact that collection of WEPs was mainly done by them during agricultural activities and on their to-and-fro journey to fields and forests for livestock-rearing activities. Gender is a crucial variable that influences the traditional knowledge of an area because it is highly correlated with numerous sociocultural factors like livelihood, education, accessibility to resources, status, and networking in the society [49]. Women of every society tend to have an edge over these sociocultural factors and hence their knowledge is much more than others [50]. As evident from the present study, women are usually unemployed in these far-flung areas and fully dedicate themselves to household and other cattle-related activities. They combine this day-to-day information with culturally attained knowledge to enhance their subsistence [51].

\section{Diversity of wild edible plants}

A total of 90 plant species (89 angiosperms and 1 pteridophyte, viz, Diplazium esculentum) belonging to 45 families and 78 genera serve as wild phytofoods in Udhampur (Table 1). Out of the 89 species of flowering plants, $95.5 \%$ (85 species) belong to dicots and $4.5 \%$ (4 species, viz, Commelina benghalensis, Tulipa clusiana, Colocasia esculenta, and Phoenix sylvestris) belong to monocots. Singh et al. [52] have reported 111 wild edible plants from Kashmir Himalayas whereas Thakur et al. [8] have recorded 50 phytofoods from tribal areas of Western Himalaya. Some other studies from different parts of the world have reported 49 to 173 wild edible plants [53-55]. The high usage of wild plants as vegetables and fruits, in the present study, is an indicator of rich diversity of plants, easy availability, deep knowledge of wild edible plants, day-to-day requirements, well-maintained forests, far-off residential places from the local markets, and/or poor economic status of the local populace.

In terms of number of species used, Leguminosae was the most dominant family (12 species) followed by Rosaceae (7 species), Moraceae (6 species), Rutaceae and Polygonaceae (5 species each), Lamiaceae (4 species), and Combretaceae (3 species) (Fig. 2). Twenty-eight families were represented by a single species each. In contrast to Rosaceae, being the most dominant family used in other studies worldwide $[8,52,54,55]$, Leguminosae was the 


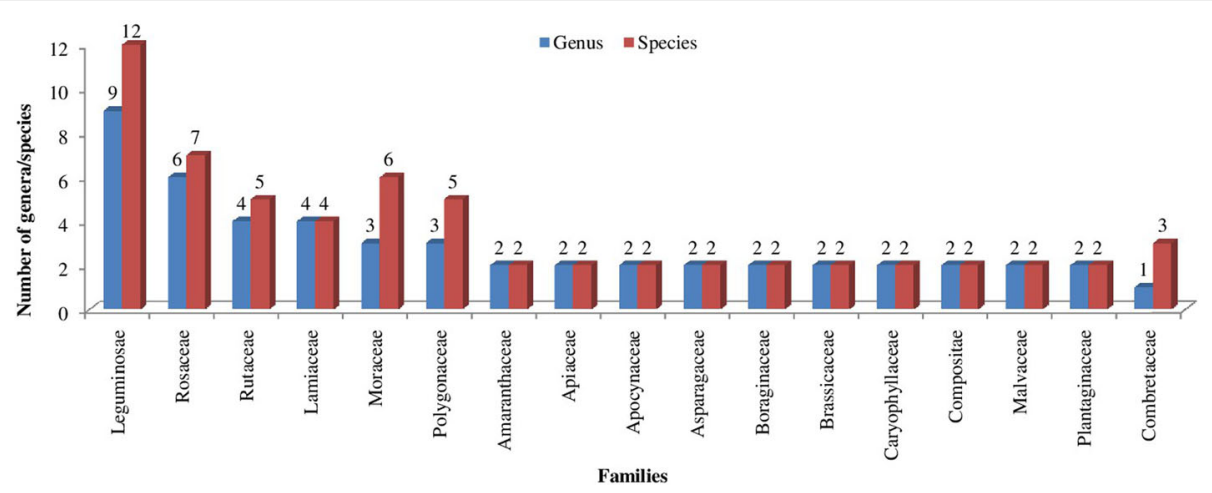

Fig. 2 Most represented wild plant families and number of genera/species in Udhampur

most important family in the present study. This may be ascribed to the dominance of Leguminosae in the local flora or higher relevance of vegetables in the day-to-day life of the local populace of Udhampur. Pardo-de-Santayana et al. [53] have reported Lamiaceae as the most important plant family in Montesinho, Portugal, owing to the higher significance of condiments in the area.

Approximately, 20.7 wild edible species were used per informant in the present study. Highest value of usage was recorded for vegetable (mean 7.2), followed by fruits (mean 6.2), and food medicine plants (mean 5.0). Thakur et al. [8] have recorded 23.7 species per respondent in the tribal areas of Himachal Pradesh, India; Geng et al. [55] have recorded an average of 20.6 taxa per informant by the Naxi in northwest Yunnan, China; Kang et al. [56] have stated an average of 20.8 wild edible species per informant from Gansu province of China, and Dolina et al. [57] have reported a mean of 13.2 and 14.6 species per informant in Poljica and Krk areas of Croatia, respectively. In all these studies, the mean number of vegetable species per informant ranged between 7.1 and 13.2 and the mean number of fruit species per respondent between 6.3 and 6.9. The values reported in the present study are well within these ranges for total wild edible species, vegetable and fruit species.

\section{Informant consensus index $\left(F_{\mathrm{ic}}\right)$}

Informant consensus index $\left(F_{\text {ic }}\right)$ varied between 0.83 for raw vegetables and 0.94 for preserved vegetables (Table 2 ). Wild fruits eaten raw and chutney preparations also recorded high values $\left(0.93\right.$ each) for $F_{\text {ic }}$. Similar results of high $F_{\text {ic }}$ values have also been reported by Rao et al. [38], Bhatia et al. [40], Bhatia et al. [41], Singh et al. [52], and Kumar et al. [58] from various parts of Jammu and Kashmir owing to high level of sharing of indigenous knowledge among the informants. These findings point towards the fact that despite huge variation in communities, climatic conditions, and forests, informants have good knowledge of WEPs which is being shared to a great extent among the inhabitants and also wild phytofoods are presently in use among the local populace.

\section{Usages of wild edible plants and cultural importance}

The present study site is having rich diversity of vegetables, fruits, and medicinal plants (Table 2). Species richness of WEPs was the maximum for vegetables (46 species) followed by fruits (37 species) and medicinal plants (36 species). Vegetables were mainly consumed after cooking (93.5\%) and fruits as raw (94.6\%). Highest use-report (626) was recorded for vegetables whereas maximum mean use-report (14.8) was recorded for fruits. Edible value was not confined to one or more plant parts. Fruits were the edible part in majority of the cases $(35.5 \%)$ followed by leaves $(26.4 \%)$, seeds $(10.0 \%)$, shoots $(8.9 \%)$, flowers $(5.5 \%)$, tubers $(4.6 \%)$, roots $(2.7 \%)$, and pods $(1.8 \%)$ (Fig. 3). The wild edibles were mainly herbs (47.8\%, 43 species) followed by trees (32.2\%, 29 species), shrubs (14.4\%, 13 species), and climbers (5.6\%, 5 species) (Fig. 4).

The cultural index value for vegetables was $34.9 \%$ of the total CI, closely followed by fruits $(30.5 \%)$ and medicinal plants (24.3\%). Culturally (on the basis of CI), the most important vegetable species were Diplazium esculentum (0.52), Fumaria indica (0.51), Taraxacum campylodes (0.50), Urtica dioica (0.49), Zanthoxylum armatum (0.42), etc. The most common fruits consumed by the locals were Phyllanthus emblica (CI, 0.94), Punica granatum (CI, 0.68), Cordia dichotoma (CI, 0.60), Syzygium cumini (CI, 0.57), Ficus palmata (CI, 0.51), Berberis lycium (CI, 0.43), Prunus armeniaca (CI, 0.33), Prunus persica (CI, 0.31), Pyrus pashia (CI, 0.22), and Rubus ellipticus (CI, 0.18).

\section{Vegetables}

Most of the species with high CI in the present study are also used as vegetable in most parts of the Himalayas $[8,15,52,59]$. The immature fronds of Diplazium esculentum are either cooked as vegetable or preserved as pickle in the study area, same as in other parts of the 
Table 2 Species richness and cultural importance of various use-categories and subcategories of wild edible plants

\begin{tabular}{|c|c|c|c|c|c|}
\hline Use-category/subcategories & Number of species & Use-report (UR) & Mean UR & $\mathrm{Cl}$ & $F_{\mathrm{ic}}$ \\
\hline Vegetables & 46 & 626 & 13.6 & 7.1 & 0.93 \\
\hline Vegetable (cooked) & 43 & 457 & 10.6 & 5.2 & 0.91 \\
\hline Vegetable (raw) & 4 & 19 & 4.8 & 0.2 & 0.83 \\
\hline Vegetable (preserved) & 10 & 150 & 15.0 & 1.7 & 0.94 \\
\hline Fruits & 37 & 547 & 14.8 & 6.2 & 0.93 \\
\hline Fruit (processed) & 9 & 73 & 8.1 & 0.8 & 0.89 \\
\hline Fruit (raw) & 35 & 474 & 13.5 & 5.4 & 0.93 \\
\hline Chutney & 10 & 138 & 13.8 & 1.6 & 0.93 \\
\hline Spices & 3 & 21 & 7.0 & 0.2 & 0.90 \\
\hline Beverage & 6 & 46 & 7.7 & 0.5 & 0.89 \\
\hline Medicinal WEPs & 36 & 436 & 12.1 & 5.0 & 0.92 \\
\hline
\end{tabular}

Himalayas $[8,15,52,59-61]$. According to Zeghichi et al. [62], vegetables gathered from the wild have diverse, potentially more nutrients than the commercially cultivated species. Seal [63] has reported the leaves of Diplazium esculentum with high moisture content to have good nutritive value $\left(3413.2 \mathrm{Kcal} \mathrm{Kg}^{-1}\right)$ and crude protein content $\left(143.8 \mathrm{~g} \mathrm{Kg}^{-1}\right)$. The values of protein content are even higher than many commercial fruits and leafy vegetables like apple, litchi, cabbage, and cauliflower [63, 64]. Taraxacum campylodes as vegetable is a rich source of proteins, calcium, phosphorus, and dietary fiber [65]. Urtica dioica has a huge local value as vegetable in India and other parts of the world [8, 37, 52, 66-68]. It is a good source of vitamin A, dietary calcium, iron, crude proteins, fiber, fat, and carbohydrates [68, 69].

Nelumbo nucifera (CI, 0.06) grows in ponds, lakes, and marshy and swampy areas. Fresh rhizome of this plant contains $83.8 \%$ water, $0.1 \%$ fat, $1.6 \%$ reducing sugar, $0.4 \%$ sucrose, $2.7 \%$ crude protein, $9.3 \%$ starch, $0.8 \%$ fiber, $1.1 \%$ ash, and $0.1 \%$ calcium [70]. Rhizomes/petioles of Nelumbo nucifera are eaten as vegetable prepared either in tomato puree or in yogurt; the dish prepared in yogurt is locally

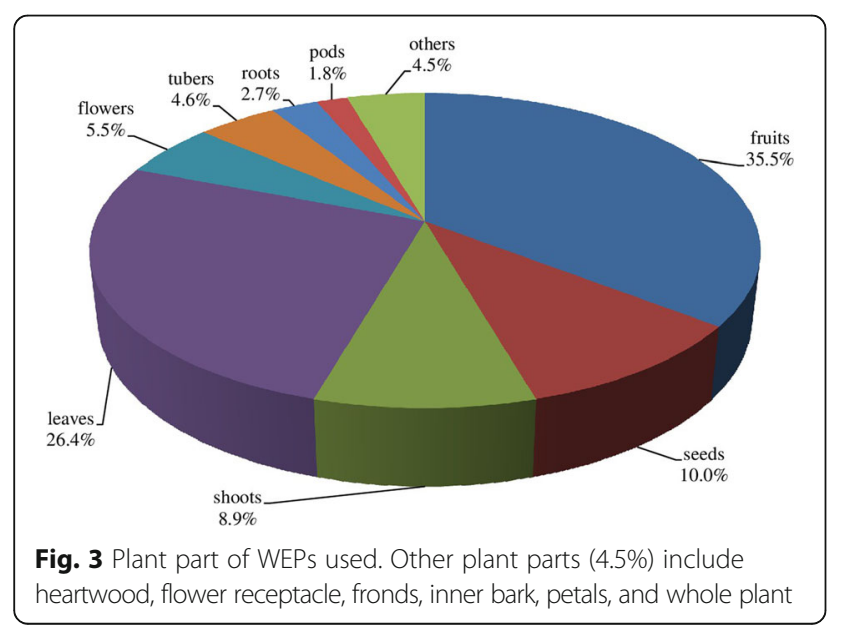

known as nadroo ki yakhni and is considered a delicacy during marriages and other festive occasions. A combination of yogurt and vegetables is also common in many Middle East countries [71].

A good number of vegetables are sun-dried or preserved as pickle (10 species). The sun-dried vegetables are meant for usage in winters, the period of scarcity, especially in the hilly zones. This is again a tradition practiced in the Himalayas; some plants are preserved in mustard oil and salt in the form of pickles, viz, young fronds of Diplazium esculentum [8,52,61], pods and roots of Moringa oleifera [35, 72], flowers of Agave americana [73], and whole plant of Ranunculus arvensis.

\section{Fruits}

Fruits are mainly consumed raw. Some of the most common fruits consumed by the locals were Phyllanthus emblica, Punica granatum, Cordia dichotoma, Syzygium cumini, Ficus palmata, Berberis lycium, Prunus armeniaca, Prunus persica, Pyrus pashia, Rubus ellipticus, etc. Arya [74] has also reported Rubus ellipticus, Pyrus pashia, Elaeagnus parvifolia, Carissa spinarum, and Ficus palmata to be wild edible fruits used by the locals of Garhwal Himalaya, India. Thakur et al. [8] have also recorded the

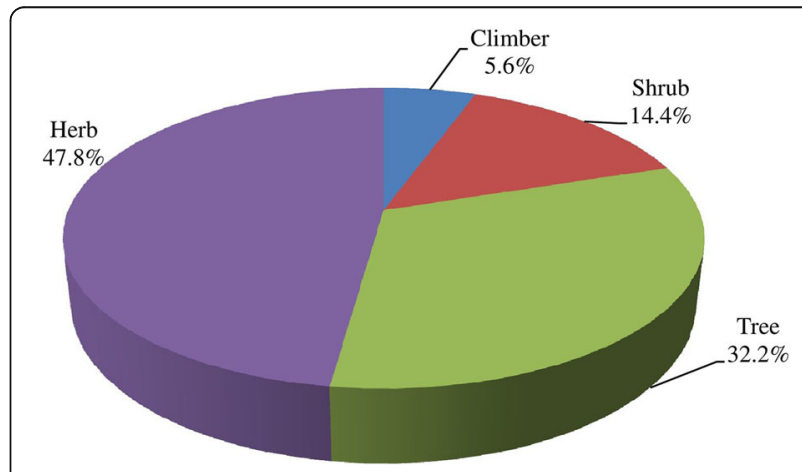

Fig. 4 Habit of WEPS 
usage of Prunus armeniaca, Pyrus pashia, Pyrus pashia, and Rubus ellipticus as raw fruits from the tribal area of Western Himalaya. As per Johns [75], wild fruits contain more fiber and have higher concentrations of vitamins and greater diversity of secondary metabolites in comparison to cultivated species.

Fruit pulp of Aegle marmelos and seeds of Ocimum basilicum are used for preparation of traditional beverage or drink (locally known as Sharbat) during summers. Both Aegle marmelos [76] and Ocimum basilicum [77] are used as drinks in various parts of India and other neighboring countries. Fruits of Phoenix sylvestris, being calorie-rich and having numerous vital and refreshing compounds, are consumed worldwide especially by Muslims during the holy month of Ramadan to break the day-long fast [78].

Some fruit species, viz, Cydonia oblonga and Phyllanthus emblica, are preserved for months or even years in the form of a local preparation called murabba (local jam) prepared by boiling whole or sliced fruits followed by shade drying and storing in airtight containers containing sugar or sugar syrup. Fruits of Artocarpus lacucha (Fig. 5), Phyllanthus emblica, and Citrus medica are preserved in mustard oil along with spices and salt as pickle. All these practices of preservation of fruits for the period of scarcity are part of local culture and also practiced in various other parts of India and in the Himalayas [8].

\section{Food medicine}

It is a well-known fact that wild edibles are used as medicines worldwide [54], and in general, these plants are called as nutraceuticals [79]. A good number of the wild edibles were reported as food medicine in the present study. They stand third, after the vegetable and fruits, in all respects as number (36 species), citations (436), and citations per informant (5.0). These species that can be a wild vegetable or fruit are consumed as per the availability or on special occasions like locals cook the leaves of Taraxacum campylodes (CI, 0.50) as vegetable especially as pre- and post pregnancy food for ladies to overcome weakness. It is a rich source of minerals particularly potassium [80] as well as protein, boron, calcium, choline, copper, iron, manganese, magnesium, potassium, silicon, and zinc [81] and a rich source of vitamins A, B complex, C, and D [40, 58, 82]. Urtica dioica (CI, 0.49) is a multi-utility medicinal species [38]. The plant is diuretic and its tender leaves are picked up and cooked as local delicacy. Cissampelos glaberrima (CI, 0.40) is consumed only at the time of diarrhea [40]. Jam (gulukand) prepared from the petals of rose after adding sugar is used
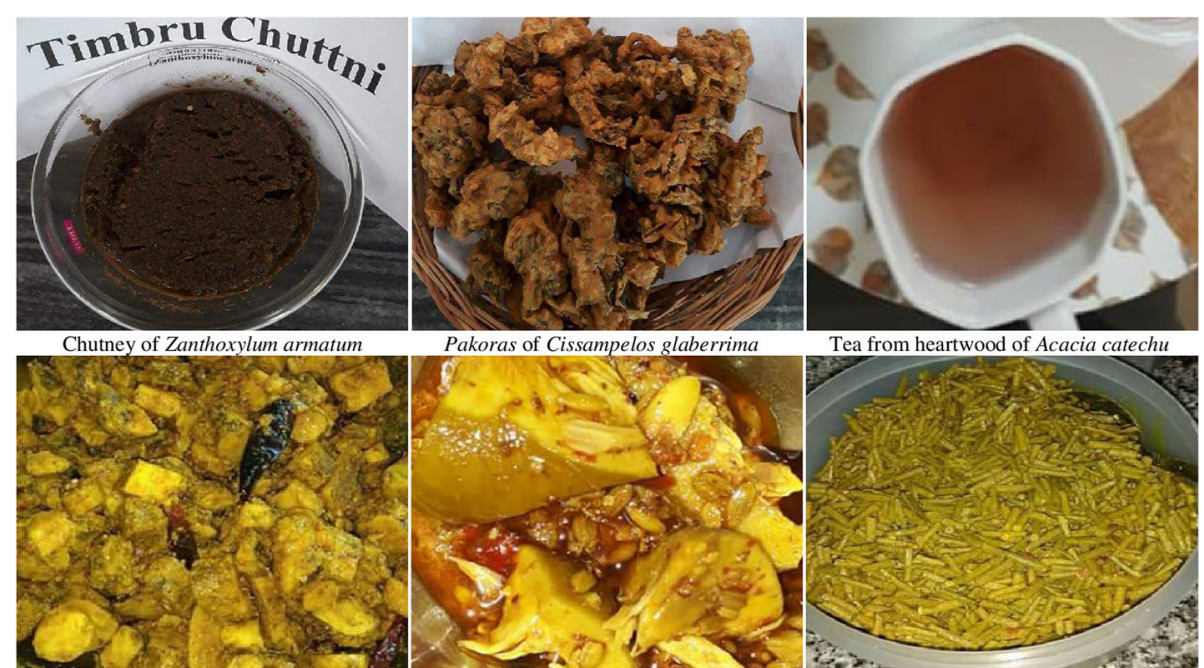

Pakoras of Cissampelos glaberrima

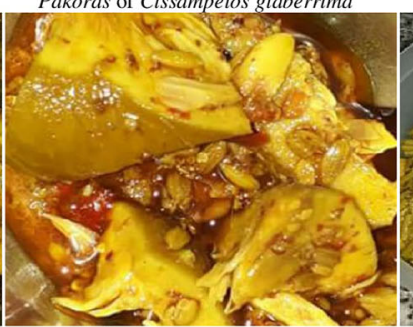

Tea from heartwood of Acacia catechu

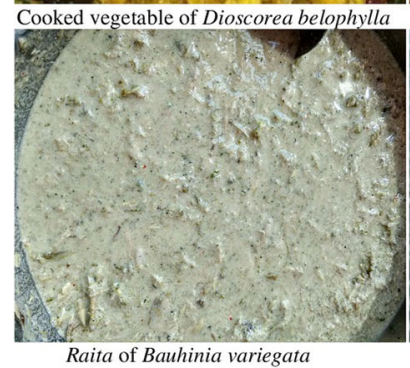

Pickle of Artocarpus lacucha
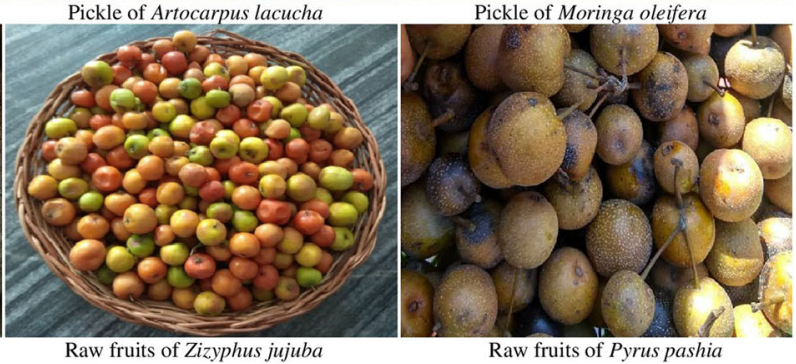

Fig. 5 Photographs of some recipes and wild raw fruits from Udhampur 
as medicine to cure mouth ulcers and improve digestion and use against jaundice.

\section{Chutney}

On an average, 1.6 wild edible species per informant were mentioned to be utilized for the preparation of chutney. Leaves of Mentha longifolia are grinded separately in mortar and pestle with subsequent addition of salt and spices resulting in the preparation of chutney. It is a ready-to-eat food for instant consumption and generally referred to as the poor man's food adjuster [83]. Chutney is part of daily meal especially during summer season as it is a very good appetizer, antigastric, and antispasmodic and improves digestion [38, 40].

Seeds of Punica granatum, Zanthoxylum armatum (Fig. 5), and Flemingia prostrata are also consumed as chutney. This recipe improves digestion and is a good appetizer [40]. Ramachandran and Ali [84] also reported the fruit and seeds of Zanthoxylum armatum to be consumed as aromatic and tonic, in fever and dyspepsia and in expelling round worm.

\section{Beverages}

In the study area, four species, viz, Viola odorata (flowers), Persicaria amplexicaulis (roots), Flacourtia indica (inner bark), and Acacia catechu (heartwood) are boiled in hot water and serve as tea substitutes (hot drinks) after adding sweeteners. Tea prepared from flowers of Viola odorata is used against cough, cold, fever, and jaundice. Viola odorata contains alkaloids, mucilage, and vitamin C [85] having diuretic [86] and antioxidant properties [87] and used against bronchitis, cancer, cold and cough, fever, kidney troubles, liver disorders, rheumatism, sneezing, and urinary infections $[88,89]$.

\section{Spices}

Owing to their aromatic properties, three species, namely Artemisia scoparia (seeds, flowers, and leaves), Carum carvi (fruits, seeds), and Murraya koenigii (leaves), are added to pulses and vegetables as condiment and spice in the study area. Carum carvi is a valuable spice found in the wild all through Europe, Russia, Siberia, and the Himalayas [90], having antibacterial, antiproligerative, antifungal, antitumor, and antihyperglycemic properties [91]. The aromatic leaves of Murraya koenigii are highly valued, in different parts of Asia, for their utility as condiment and spice [60, 92-94] and for medicinal properties such as antidiabetic, antidysenteric, antioxidant, anti-inflammatory, anticarcinogenic, and hepatoprotective [93, 94].

\section{Conclusions}

Hunger, one of the most important concerns of this generation, can be supplemented, to a great extent, by the inclusion of WEPs in diet. Present study revealed that the traditional knowledge about the use of WEPs is still in practice among the ethnic communities of the study area. High diversity of vegetable, fruit, and food medicine plants in use along with greater consensus for their usage also supports this statement. The informants depend on these resources, developed in an agricultural and pastoral context, not only for food and nutrition but also for income generation. The culturally important plants of the study site are also common in use in other parts of the Himalayas which shows that broadly the dweller of the great Himalayan range have some similarities in their traditions. Persistence with the conventional foods is a powerful tool in the conservation of ethnic identity and cultures. So, the need of the hour is that the national and international authorities recognize the contribution of rural communities to the diversification of human nutrition and work in collaboration for the reappraisal of folk knowledge on WEPs.

\section{Acknowledgements \\ Not applicable. \\ Funding \\ No funding was received for this research. This is a self-financed study.}

Availability of data and materials

All data generated or analyzed during the conduct and writing up of the manuscript is incorporated in the research article.

\section{Authors' contributions}

$\mathrm{HB}$ and KK carried out field surveys and collected the data. RKM and YPS planned the study and reviewed the final manuscript. RKM and HB did the data analysis and wrote the manuscript. All the authors have read the final manuscript and hereby approved it.

Ethics approval and consent to participate

Not applicable.

Consent for publication

Not applicable.

Competing interests

The authors declare that they have no competing interests.

\section{Publisher's Note}

Springer Nature remains neutral with regard to jurisdictional claims in published maps and institutional affiliations.

\section{Author details}

${ }^{1}$ Department of Botany, University of Jammu, Jammu, J\&K 180001, India. ${ }^{2}$ Department of Botany, Govt. Degree College, Kathua, J\&K 184104, India. ${ }^{3}$ Department of Botany, Govt. Degree College for Women, Udhampur, J\&K 182101, India.

Received: 4 July 2018 Accepted: 8 November 2018

Published online: 29 November 2018

References

1. Beluhan S, Ranogajec A. Chemical composition and non-volatile components of Crotial wild edible mushrooms. Food Chem. 2010;124:1076-82.

2. Schippmann U, Cunningham AB, Leaman DJ. Impact of cultivation and gathering of medicinal plants on biodiversity: global trends and issues. In: Biodiversity and the ecosystem approach in agriculture, forestry and fisheries. Rome: FAO; 2002. 
3. Grivetti LE, Ogle BM. Value of traditional foods in meeting macro- and micro nutrient needs: the wild plant connection. Nutr Res Rev. 2000; 13(1):31-46.

4. Mohan Ram HY. Plant Resources of Indian Himalaya 9th G P Pant Memorial Lecture, G B Pant Institute of Himalayan Development. Gangtok: Sikkim; 2000.

5. Burlingame B. Wild nutrition. J Food Composition Analysis. 2000;13:99-100.

6. TB G-D, Maass L, Isselstein J. Plant biodiversity and ethnobotany of Borana pastoralists in southern Oromla, Ethiopia. Eco Bot. 2005;59:43-65.

7. Shrestha PM, Dhillion SS. Diversity and traditional knowledge concerning wild food species in a locally managed forest in Nepal. Agrofor Syst. 2006; 66:55-63.

8. Thakur D, Sharma A, Uniyal SK. Why they eat, what they eat: patterns of wild edible plants consumption in a tribal area of Western Himalaya. J Ethnobiol Ethnomed. 2017:13:70.

9. Wehmeyer AS, Rose EF. Importance indigenous plants used in the Transke as food supplements. Bothalia. 1983;14:613-5.

10. Ogle BM, Grivetti LE. Legacy of the chameleon edible wild plants in the Kingdom of Swaziland, South Africa a cultural, ecological, nutritional study parts II-IV, species availability and dietary use, analysis by ecological zone. Ecol Food Nutr. 1985:17:1-30.

11. MS A-S, Jamous RM, JH A-S, Elgharabah WA, Kherfan FA, Qarariah KH, Khdair IS, Soos IM, Musleh AA, Isa BA, Herzallah HM, Khlaif RB, Aiash SM, Swaiti GM, Abuzahra MA, MM H-A, Saifi NA, Azem HK, Nasrallah HA Traditional knowledge of wild edible plants used in Palestine (northern West Bank): a comparative study. J Ethnobiol Ethnomed. 2008;4:13.

12. Hussain J, Hussain H, Shinwari ZK, Ahmad I, Hussain ST, Ahmad V. Antibacterial activity of the chemical constituents from Ranunculus laetus. Chem Nat Compd. 2009;45(5):720-1.

13. Shackleton SE, Dzeferos CM, Shackleton CM, Mathabela FR. Use and trading of edible herbs in the central Lowveld savanna region, South Africa. Econ Bot. 1998:52(3):251-9.

14. Balemie K, Kebebew F. Ethnobotanical study of wild edible plants in Derashe and Kucha districts. South Ethiopia J Ethnobiol Ethnomed. 2006;2:53.

15. Misra S, Maikhuri RK, Kala CP, Rao KS, Saxena KG. Wild leafy vegetables: a study of their subsistence dietetic support to the inhabitants of Nanda Devi biosphere reserve India. J Ethnobiol Ethnomed. 2008:4:15.

16. Hussain J, Khan AL, Rehman N, Hamayun M, Shah T, Nisar M, Bano T, Shinwari ZK, Lee I. Proximate and nutrient analysis of selected vegetable species: a case study of Karak region. Pakistan Afr J Biotechnol. 2009;8(12):2725-9.

17. N'danikou S, Achigan-Dako EG, JLG W. Eliciting local values of wild edible plants in southern Bénin to identify priority species for conservation. Eco Bot. 2011;65(4):381-95

18. Sebastian MK, Bhandari MK. Edible wild plants of the forest areas of Rajasthan. J Econ Taxon Bot. 1990;14(3):689-94.

19. Bora HR, Pandey AK. Less known wild food plants of Assam. J econ taxon bot (Addl Ser). 1996;12:357-8.

20. Girach RD, Aminuddin Ahmed I. Observations on wild edible plants from tribal pockets of Orissa. PI Sci Res. 1988;10(1):16-25.

21. Islami A, Jha RK. Ethnomedicinal studies on wild edible plants of Ranchi District in Jharkhand. J Non-Timber Forest Prod. 2001:8:29-33.

22. Sharma PP, Singh NP. Ethnomedicinal uses of some edible plants of Dadra, Nagar Haveli and daman (UT). Ethnobotany. 2001;13:121-5.

23. Patole SN, Jain AK. Some wild edible plants of Pachmarhi biosphere reserve (MP). Ethnobotany. 2002;14:48-51.

24. Pundir YPS, Singh D. Ethnobotanical wild food plants of Jaunsar-Bawar (Western Himalaya). Uttaranchal Indian Forester. 2002;128(5):571-82.

25. Kulkarni DK, Agte W, Kumbhojkar MS. Leafy vegetables consumed by Mahadeokoli tribe in Western Maharashtra with their nutritional potential. Ethnobotany. 2003;15:34-8.

26. Kumer V. Wild edible plants of Surguja District of Chattisgarh state. India J Econ Taxon Bot. 2003;27(2):272-82.

27. Devi M. Wild edible plants of Sonipur District. Assam J Econ Taxon Bot. 2003:27(2):396-409.

28. Nandanakunjidam S. Some less known wild food plants of Attapadi Hills Western Ghats J Econ Taxon Bot. 2003;27(3):741-5.

29. Prasad VK, Raja Gopal T, Badrinath KVS. Notes on economic importance of wild plants of Rampa-East Godavari District. Andhra Pradesh India J Econ Taxon Bot. 2003;27(3):603-12.
30. Arora RK, Anjula P. Wild edible plants of India: diversity conservation and use. India: ICAR New Delhi; 1996.

31. Rathore M. Nutrient content of important fruit trees from arid zone of Rajasthan. J Hort Forestry. 2009;1:103.

32. Atal CK, Sharma BM, Bhatia AK. Search of emergency food through wild flora of Jammu and Kashmir State. Sundarbani area I Indian Forester. 1980; 106(3):211-9.

33. Kaul AK, Karihaloo JL, Hamal IA. Wild edible plants of Kashmir - some less known vegetable substitutes and beverages. Bull Bot Surv India. 1982; 24(1-4):67-9.

34. Kaul MK, Sharma PK, Singh V. Ethnobotanical studies in north-west and trans-Himalaya IV some traditionally tea substitutes from J K state. Himalayan. Plant J. 1987:4:23-8.

35. Srivastava TN. Wild edible plants of Jammu and Kashmir state - an ethnobotanical study. Anc Sci Life. 1988;8(3\&4):201-6.

36. Rashid A, Anand VK, Serwer J. Less known wild edible plants used by the Gujjar tribe of district Rajouri, Jammu and Kashmir state - India. Int J Bot. 2008;4(2):219-24.

37. Luczaj L, Koncic MZ, Milicevic T, Dolina K, Pandza M. Wild vegetable mixes sold in markets of Dalmatia (southern Croatia). J Ethnobiol Ethnomed. 2013;9(1):2.

38. Rao PK, Hasan SS, Bhellum BL, Manhas RK. Ethnomedicinal plants of Kathua district, J\&K, India. J Ethnopharmacol. 2015;171:12-27.

39. Reyes-Garcia V, Menendez-Baceta G, Aceituno-Mata L, Acosta-Naranjo R, Calvet-Mir L, Dominguez P, Rodriguez-Franco R. From famine food to delicatessen: interpreting trends in the use of wild edible plants through cultural ecosystem services. Ecol Econ. 2015;120:303-11.

40. Bhatia H, Sharma YP, Manhas RK, Kumar K. Ethnomedicinal plants used by the villagers of district Udhampur, J\&K, India. J Ethnopharmacol. 2014;151(2): 1005-18.

41. Bhatia H, Sharma YP, Manhas RK, Kumar K. Traditional phytoremedies for the treatment of menstrual disorders in district Udhampur, J\&K, India. J Ethnopharmacol. 2015;160:202-10.

42. Balick MJ, Cox PA. Plants, people, and culture: the science of ethnobotany. Scientific American library. New York: WH Freeman; 1996.

43. Sharma BM, Kachroo P. Flora of Jammu and plants of neighbourhood. Dehradun, India: Bishen Singh Mahender pal Singh; 1983.

44. Swami A, Gupta BK. Flora of Udhampur. Dehradun, India: Bishen Singh Mahendra pal Singh; 1998.

45. Heinrich M, Ankli A, Frei B, Weimann C, Sticher O. Medicinal plants in Mexico: healers' consensus and cultural importance. Soc Sci Med. 1998;47:1863-75.

46. Gazzaneo LRS, Lucena RFP, Albuquerque UP. Knowledge and use of medicinal plants by local specialists in a region of Atlantic Forest in the state of Pernambuco (northeastern Brazil). J Ethnobiol Ethnomed 2005;1: doi:101186/ 1746-4269-1-9.

47. Sharma R, Manhas RK, Magotra R. Ethnoveterinary remedies of diseases among Milk yielding animals in Kathua, Jammu and Kashmir, India. J Ethnopharmacol. 2012;141(1):265-72.

48. Tardio J, Pardo-de-Santayana M. Cultural importance indices: a comparative analysis based on the useful wild plants of southern Cantabria (northern Spain). Econ Bot. 2008;62:24-39.

49. Pfeiffer J, Butz R. Assessing cultural and ecological variation in ethnobiological research: the importance of gender. J Ethnobiol. 2005:25:240-78.

50. Junsongduang A, Balslev H, Inta A, Jampeetong A, Wangpakapattanawong P. Karen and Lawa medicinal plant use: uniformity or ethnic divergence? J Ethnopharmacol. 2014;151:517-27.

51. Garibay-Orijel R, Ramírez-Terrazo A, Ordaz-Velázquez M. Women care about local knowledge, experiences from ethnomycology. J Ethnobiol Ethnomed. 2012;8:25.

52. Singh B, Sultan P, Hassan QP, Gairola S, Bedi YS. Ethnobotany, traditional knowledge and diversity of wild edible plants and fungi: a case study in the Bandipora District of Kashmir Himalaya, India. Journal of Herbs, Spices and Medicinal Plants. 2016;22(3):247-78

53. Pardo-de-Santayana M, Tardío J, Blanco E, Carvalho AN, Lastra JJ, Miguel ES, Morales R. Traditional knowledge of wild edible plants used in the northwest of the Iberian Peninsula (Spain and Portugal): a comparative study. J Ethnobiol Ethnomed. 2007;3:27

54. Menendez-Baceta G, Aceituno-Mata L, Reyes-García V, Tardío J, Salpeteur M, Pardo-de-Santayana M. The importance of cultural factors in the distribution of medicinal plant knowledge: a case study in four Basque regions. J Ethnopharmacol. 2015;161:116-27. 
55. Geng Y, Zhang Y, Ranjitkar S, Huai H, Wang Y. Traditional knowledge and its transmission of wild edibles used by the Naxi in Baidi Village, northwest Yunnan province. J Ethnobiol Ethnomed. 2016;12:10.

56. Kang J, Kang Y, Ji X, Guo Q, Jacques G, Pietras M, Luczaj N, Li D, Luczaj L. Wild food plants and fungi used in mycophilous Tibetan community of Zhagana [Tewo County, Gansu, China]. J Ethnobiol Ethnomed. 2016;12(1):21.

57. Dolina K, Jug-Dujakovic M, Luczaj L, Vitasovic-Kosic I. A century of changes in wild food plant use in coastal Croatia: the example of Krk and Poljica. Acta Soc Bot Pol. 2016;85(3):3508.

58. Kumar K, Sharma YP, Manhas RK, Bhatia H. Ethnomedicinal plants of Shankaracharya Hill, Srinagar, J\&K, India. J Ethnopharmacol. 2015;170:255-74.

59. Kumar S, Hamal IA. Wild edibles of Kishtwar high altitude national park in northwest Himalaya, Jammu and Kashmir (India). Ethnobotanical Leaflets. 2009;13:195-202.

60. Singh S, Omre PK, Mohan SM. Curry leaves (Murraya koenigii) - a miracle plant Indian. J Sci Res. 2014;4(1):46-52.

61. Tag H, Tsering J, Hui PK, Gogoi BJ, Veer V. Nutritional potential and traditional uses of high altitude wild edible plants in eastern Himalayas, India international. Journal of biological, veterinary, agricultural and food. Engineering. 2014;8(3):226-31.

62. Zeghichi S, Kallithraka S, Simopoulos AP, Kypriotakis Z. Nutritional composition of selected wild plants in the diet of Crete. World Rev Nutr Diet. 2003;91:22-40.

63. Seal T. Antioxidant activity of some wild edible plants of Meghalaya state of India: a comparison using two solvent extraction systems. Int J Nutr Metabol. 2012:4(3):51-6.

64. Gopalan C, Ramasastry BV, Balasubramanian SC. Nutritive value of Indian foods. AP, India: Indian Council of Medical Research Hyderabad; 2004

65. Escudero NL, Arellano ML, Albarracín SFG, Mucciarelli S. Taraxacum officinale as a food source. Plant Foods Hum Nutr. 2003:58:1-10.

66. Lopatkin N, Sivkov A, Schläfke S, Funk P, Medvedev A, Engelmann U. Longterm efficacy and safety of a combination of sabal and urtica extract for lower urinary tract symptoms-a placebo-controlled, double-blind, multicenter trial. World J Urol. 2005;23(2):139-46.

67. di TA, Łuczaj , Quave CL, Redzic S, Pieroni A. Traditional food and herbal uses of wild plants in the ancient south-Slavic diaspora of Mundimitar/ Montemitro (southern Italy). J Ethnobiol Ethnomed. 2012;8:21.

68. Rutto LK, Xu Y, Ramirez E, Brandt M. Mineral properties and dietary values raw and processed stinging nettle (Urtica dioica L.). Int J Food Sci 2013:doi: 101155/2013/857120.

69. Adhikari BM, Bajracharya A, Shrestha AK. Comparison of nutritional properties of stinging nettle (Urtica dioica) flour with wheat and barley flours. Food Science \& Nutrition. 2016:4(1):119-24.

70. Mukherjee PK, Balasubramanian R, Pal M, Saha BP. Studies on psycho pharmacological effects of Nnucifera rhizome extract. J Ethnopharmacol. 1996;54:63-7.

71. Ottogalli G, Testolin G. Dairy products in the Mediterranean diets in health and disease. In: Spiller, GA (Ed). New York: The Mediterranean Diets in Health and Disease Van Nostrand Reinhold. p. 1991.

72. Verma S, Chauhan NS. Indigenous medicinal plants knowledge of Kunihar forest division. Indian J Tradit Knowl. 2005;6:494-7.

73. Arya D. Major wild edible fruits used by the locals of Garhwal Himalaya. International Journal of Advanced Life Sciences. 2013;6(3):145-9.

74. Johns T. With bitter herbs they shall eat it: chemical ecology and the origins of human diet and medicine. Tucson: The University of Arizona Press, Arizona; 1990.

75. Khandare MS. Bael (Aegle marmelos): A Kalpavraksha. Journal of Medicinal Plants Studies. 2016;4(2):13-4

76. Hosseini-Parvar SH, Matia-Merino L, Goh KKT, Razavi SMA, Mortazavi SA Steady shear flow behaviour of gum extracted from basil seed (Ocimum basilicum L): effect of concentration and temperature. J Food Eng. 2010;101:236-43.

77. Al-Shahib W, Marshall RJ. The fruit of the date palm: its possible use as the best food for the future. Int J Food Sci Nutr. 2003;54:247-59.

78. Heinrich M, Leonti M, Nebel S, Peschel W. Local food nutraceuticals: an example of a multidisciplinary research project on local knowledge. J Physiol Pharmacol. 2005:56:5-22.

79. Hook I, McGee A, Henman M. Evaluation of dandelion for diuretic activity and variation in potassium content. Int J Pharmacogn. 1993;31:29-34.

80. Queralt I, Ovejero M, Carvalho ML, Marques AF, Llabrés JM. Quantitative determination of essential and trace element content of medicinal plants and their infusions by XRF and ICP techniques. X-Ray Spectrom. 2005;34:213-7.
81. US Department of Agriculture. Phytochemical Database Agricultural Research. Service-National Germplasm Resources Laboratory. Beltaville, MD: Beltaville Agricultural Research Centre; 2003.

82. Balaswamy K, Satyanayayana A, Rao DG. Studies on preparation and storage characteristics of onion (Allium cepa) - chilly (Capsicum annum) chutney. Journal of Food. 2005;15:140-6.

83. Ramchandran R, Ali M. Chemical composition of fruit oil of Zanthoxylum armatum. Hamdard Med. 1996;42:51-4.

84. Stuart M. The encyclopedia of herbs and herbalism. Spain: Macdonald \& Co (Publishers) Ltd; 1989.

85. Vishal A, Parveen K, Pooja S, Kannappan N, Kumar S. Diuretic, laxative and toxicity studies of Viola odorata aerial parts. Pharmacol Online. 2009;1:739-48.

86. Ebrahimzadeh MA, Nabavi SM, Nabavi SF, Bahramian F, Bekhradnia AR Antioxidant and free radical scavenging activity of $H$. officinalis $L$. var angustifolius, V. odorata, B. hyrcana and C. speciosum. Pakistan journal of pharma Science. 2010;23(1):29-34.

87. Kritikar KR, Basu BD. Indian medicinal plants. India: International Book Distributors; 1999.

88. Nadkarni KM. The Indian Materia Medica. India: Bombay Popular Prakashan Publishers; 2009

89. Gwari G, Bhandari U, Andola HC, Lohani H, Chauhan N. Aroma profile of seeds of Carum carvi Linn cultivated in higher hills of Uttarakhand Himalaya. Indian J Nat Prod Resour. 2012;3:411-3.

90. Gupta A, Dubey M, Parmar M, Mahajan S, Sharma R. Evaluation of antimicrobial activity of Carum carvi (seeds) extract against $E$ coli and Aspergillus niger. Drug Invention Today. 2011;3:211-3.

91. Saini SC, Reddy GBS. Murraya koenigii. Journal of Pharmacy and Biological Sciences. 2013;7(6):15-8

92. Igara CE, Omoboyowa DA, Ahuchaogu AA, Orji NU, Ndukwe MK. Phytochemical and nutritional profile of Murraya koenigii (L.) Spreng leaf. Journal of Pharmacognosy and Phytochemistry. 2016;5(5):07-9.

93. Jain M, Gilhotra R, Singh RP, Mittal J. Curry leaf (Murraya koenigii): a spice with medicinal property MOJ Biol Med 2017;2(3):00050 DOI: 1015406/ mojbm20170200050

94. Kirupa SLS, Kariitha R. Anti-oxidant enhancing property of curry leaf powder Murraya keonigii in type II diabetes mellitus. International Journal of Pharmacy and Biosciences. 2015;6(1):507-14.

Ready to submit your research? Choose BMC and benefit from:

- fast, convenient online submission

- thorough peer review by experienced researchers in your field

- rapid publication on acceptance

- support for research data, including large and complex data types

- gold Open Access which fosters wider collaboration and increased citations

- maximum visibility for your research: over $100 \mathrm{M}$ website views per year

At BMC, research is always in progress.

Learn more biomedcentral.com/submissions 